\title{
Climate change impacts on runoff in West Africa: a review
}

\author{
P. Roudier ${ }^{1}$, A. Ducharne ${ }^{2}$, and L. Feyen ${ }^{1}$ \\ ${ }^{1}$ Climate and Risk Management Unit, Institute for Environment and Sustainability (IES), Joint Research Centre (JRC), \\ European Commission (EC), Ispra, Italy \\ ${ }^{2}$ Laboratoire METIS, UPMC/CNRS - UMR7619, Université Pierre et Marie Curie, Paris, France \\ Correspondence to: P. Roudier (philippe.roudier@jrc.ec.europa.eu)
}

Received: 16 January 2014 - Published in Hydrol. Earth Syst. Sci. Discuss.: 26 February 2014

Revised: 10 June 2014 - Accepted: 25 June 2014 - Published: 31 July 2014

\begin{abstract}
This review summarizes the impacts of climate change on runoff in West Africa, assesses the uncertainty in the projections and describes future research needs for the region. To do so, we constitute a meta-database made of 19 studies and 301 future runoff change values. The future tendency in streamflow developments is overall very uncertain (median of the 301 points is $0 \%$ and mean $+5.2 \%$ ), except for (i) the Gambia River, which exhibits a significant negative change (median $=-4.5 \%$ ), and (ii) the Sassandra and the Niger rivers, where the change is positive $(+14.4 \%$ and $+6.1 \%)$. A correlation analysis revealed that runoff changes are tightly linked to changes in rainfall $(R=0.49)$, and to a smaller extent also to changes in potential evapotranspiration. Other parameters than climate - such as the carbon effect on plant water efficiency, land use dynamics or water withdrawals - could also significantly impact on runoff, but they generally do not offset the effects of climate change. In view of the potential changes, the large uncertainty therein and the high vulnerability of the region to such changes, there is an urgent need for integrated studies that quantify the potential effects of these processes on water resources in West Africa and for more accuracy in climate models rainfall projections. We especially underline the lack of information concerning projections of future floods and droughts, and of interannual fluctuations in streamflow.
\end{abstract}

\section{Introduction}

Surface water is fundamental for many sectors in West Africa (WA), including agriculture, power generation and fisheries. Even if most of the agriculture in the area is rainfed, some regions strongly depend on surface water. For example, the
Office du Niger produces 40 to $50 \%$ of total rice production of Mali (Bélières et al., 2011) thanks to the Markala dam on the Niger River. Surface water collected through big dams on large rivers is also a major source of power generation in WA. The Niger River, for example, currently has a 2004 MW maximum power generation (Skinner et al., 2009), and this value could increase in the future as the power demand is dramatically increasing $\left(+17 \%\right.$ year $\left.^{-1}\right)$. Finally, fisheries strongly rely on river discharge. The drought conditions occurring in WA in the 1970s and 1980s caused a drop of $-50 \%$ in fisheries production of the Niger delta, resulting in a loss of about USD 20 million per year (Neiland and Béné, 2008).

River discharge is affected by several drivers such as land use changes, water withdrawals and climate variations. As underlined by the above example, variability in climate, and especially in rainfall, plays a significant role in flow variation. In view of global warming, which will affect key climate variables such as rainfall and temperature, changes in hydrological regimes could become even more important in the future (Wuebbles and Ciuro, 2013). In combination with the increasing demographic pressure and low adaptive capacity, these changes could therefore have significant impacts on people and sectors that depend on the availability of water in WA. As stated by UNECA and ACPC (2011), there is thus a need to study the impacts of climate change on runoff regimes in Africa and to assess the uncertainty of such projections. This is particularly true for West Africa, where "little work has been done on the future impact of climate change on water resources" (ENDA-TM, 2007).

To date, relatively few studies have assessed the impacts of climate change on hydrological regimes in WA and a clear picture of possible changes is lacking. In order to fill this gap, we perform a review of the existing literature to summarize 
Table 1. Characteristics of the selected rivers. All values come from the Global Runoff Data Centre (GRDC).

\begin{tabular}{llll}
\hline River & $\begin{array}{l}\text { Mean } \\
\text { annual } \\
\text { flow }\end{array}$ & $\begin{array}{l}\text { Catchment } \\
\text { area }\end{array}$ & $\begin{array}{l}\text { Length of upstream } \\
\text { mainstem (and total } \\
\text { length) }\end{array}$ \\
\hline Niger (Malanville) & $1053 \mathrm{~m}^{3} \mathrm{~s}^{-1}$ & $1000000 \mathrm{~km}^{2}$ & $2367 \mathrm{~km}(3478 \mathrm{~km})$ \\
Senegal (Dagana) & $687 \mathrm{~m}^{3} \mathrm{~s}^{-1}$ & $268000 \mathrm{~km}^{2}$ & $1550 \mathrm{~km}(1757 \mathrm{~km})$ \\
Black Volta (Bamboi) & $263 \mathrm{~m}^{3} \mathrm{~s}^{-1}$ & $134200 \mathrm{~km}^{2}$ & $843 \mathrm{~km}(1355 \mathrm{~km})$ \\
White Volta (Pwalagu) & $125 \mathrm{~m}^{3} \mathrm{~s}^{-1}$ & $63350 \mathrm{~km}^{2}$ & $555 \mathrm{~km}(1334 \mathrm{~km})$ \\
Volta (outlet) & $1106 \mathrm{~m}^{3} \mathrm{~s}^{-1}$ & $394100 \mathrm{~km}^{2}$ & $1245 \mathrm{~km}$ \\
Gambia (Gouloumbou) & $149 \mathrm{~m}^{3} \mathrm{~s}^{-1}$ & $42000 \mathrm{~km}^{2}$ & $451 \mathrm{~km}(799 \mathrm{~km})$ \\
Sassandra (Soubre) & $331 \mathrm{~m}^{3} \mathrm{~s}^{-1}$ & $62000 \mathrm{~km}^{2}$ & - \\
Bani (Mopti) & $1101 \mathrm{~m}^{3} \mathrm{~s}^{-1}$ & $281600 \mathrm{~km}^{2}$ & $1004 \mathrm{~km}(3457 \mathrm{~km})$ \\
Benue (Yola) & $22 \mathrm{~m}^{3} \mathrm{~s}^{-1}$ & $107000 \mathrm{~km}^{2}$ & $431 \mathrm{~km}(1541 \mathrm{~km})$ \\
\hline
\end{tabular}

the impacts of climate change on runoff in WA, to assess the uncertainty of the projections and to describe future research needs for the region. More specifically, we build a metadatabase with the results of the available studies (Sect. 2.3), and we use it in Sect. 3 to (i) quantify the overall impact of climate change on mean annual discharge in WA; (ii) focus specifically on each river of the area; (iii) study the relative role of climate variables in discharge evolution; (iv) detail how extremes and interannual variability could change in the future; and (v) assess the impacts of climate vs. the impacts of other drivers such as land use, water withdrawal and increasing carbon concentration.

\section{Area and methodology}

\subsection{Area}

We focus in this review on some of the main West African rivers (Fig. 1a and Table 1): Niger, Volta, Senegal, Gambia and Sassandra rivers. We did not find in the existing literature studies about other West African rivers, or they were not directly usable. WA is a region with very different climatic conditions. Its northern part is dry (between 300 and $500 \mathrm{~mm} \mathrm{year}^{-1}$ for the so-called Sahelian area; see FAO, 2004), while the south is much wetter, with some areas receiving more than $2000 \mathrm{~mm}_{\text {year }}{ }^{-1}$. In the part where annual precipitation is below $1100 \mathrm{~mm}_{\text {year }}{ }^{-1}$, encompassing the Sahelian, Sudano-Sahelian (500-900 $\mathrm{mm}$ year $^{-1}$ ) and Sudanian areas (900-1100 mm year $^{-1}$ ), rainfall occurs during a single rainy season whose core months are July, August and September and which is caused by the shift of the Intertropical Convergence Zone (ITCZ) to the north (Sultan, 2002). In the southernmost area, called Guinean (> $1100 \mathrm{~mm} \mathrm{year}^{-1}$ ), there are two rainy periods, namely the short one ranging from September to November and the long one, from March to July, that occur at each passage of the ITCZ. The seasonal pattern of rainfall leads to strong intra-annual streamflow variations. Figure 1b shows the average hydrographs for the

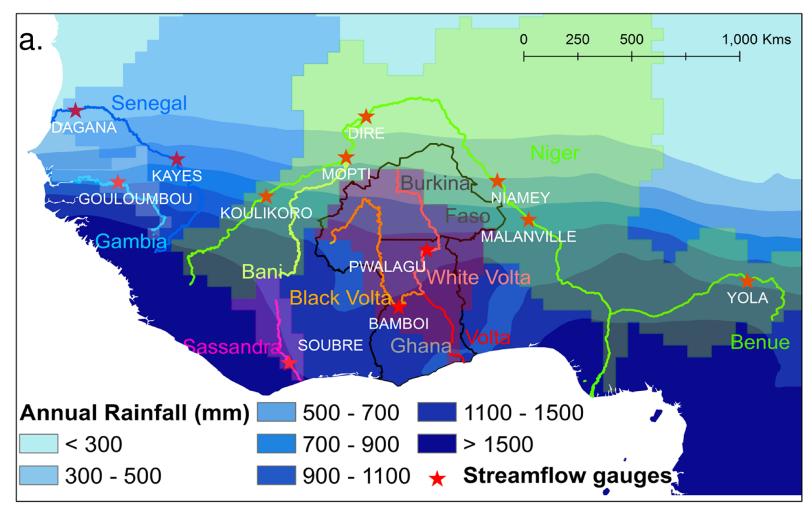

b.

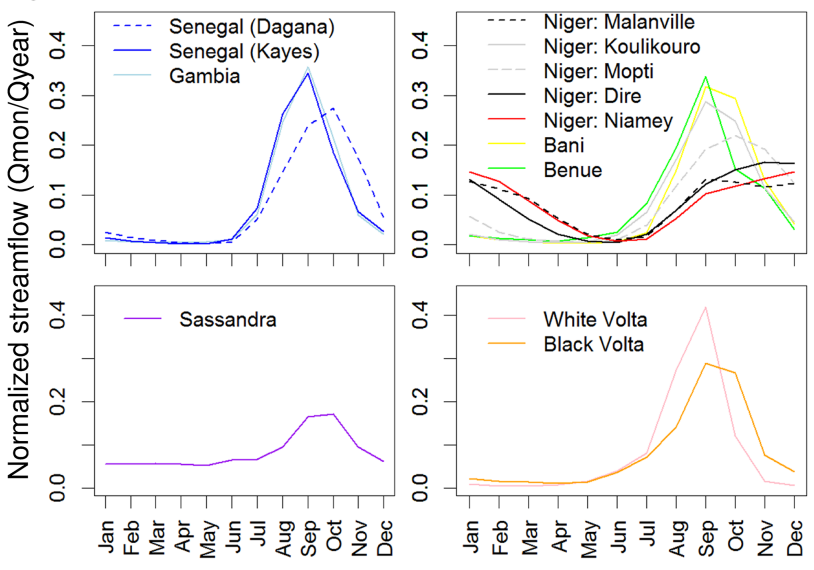

Figure 1. (a) Rivers selected in this study. Rainfall values are from CRU 3.1 data set (1970/2009) (Mitchell and Jones, 2005). Note that White Volta is also named Nakambe River. (b) Mean normalized hydrographs of the studied river basins $\left(Q_{\text {month }} / Q_{\text {year }}\right)$. Historical data come from the Global Runoff Data Centre (2011) (GRDC) and are for different time periods, depending on the river, but with at least 27 years. 
selected rivers, based on the rescaled flow ( $\left.Q_{\text {month }} / Q_{\text {year }}\right)$. They underline the differences among rivers (e.g., Niger vs. Senegal) but also within a river basin. The latter is because the drainage basins of some rivers in WA can be very large, especially for the Niger (circa $2.1 \times 10^{6} \mathrm{~km}^{2}$ ), and as a consequence include strongly contrasted climatic and agro-ecological regions. The upper Niger River hydrograph (Mopti, Koulikouro, Bani River), for example, depicts a much sharper high flow peak than its downstream counterpart (Niamey, Malanville, Dire) because of the size of the basin, and because of the inner delta, where peak discharge is strongly attenuated by flooding and evaporation. This is also expressed by the time of occurrence of high flows, which is in September-October for the upstream Niger reaches and December-January for the more downstream ones.

\subsection{Factors influencing runoff}

In order to assess future runoff changes, four key processes have to be taken into account (Sterling et al., 2013): climate variability and change, changes in land use, changes in water consumption/withrdrawls and carbon effect on plant water use.

\subsubsection{Climate variability and change}

Several studies have shown that discharge evolutions over the past decades in WA have been strongly affected by rainfall variations. After the wet 1950s and 1960s, a strong rainfall deficit has been happening since 1970 in the Sahelian and Sudano-Sahelian areas (e.g., Paturel et al., 2003), with some dramatic droughts like the 1973/1974 and 1983/1984 ones. Recent studies such as Lebel and Ali (2009), however, suggest a recovery of the rain in eastern parts of WA, whereas drought conditions endure in western regions. These rainfall variations have led to strong fluctuations in river discharge with a generally negative trend from 1960 to 2010 (Descroix et al., 2013), especially in Sudanian areas. In Guinean areas the decrease has been more moderate. Mahe et al. (2013) underlined the nonlinear effect of this rainfall drop over much of WA, with a $-20 \%$ decrease in rainfall resulting in a decrease of $-60 \%$ in runoff.

Climate models project important climate changes for the 21 st century, in WA as well as in the rest of the world, with potential impacts on the hydrological cycle. Projections all agree on a warming in WA even though its magnitude ranges from +2 to $+6{ }^{\circ} \mathrm{C}$ in 2100 across climate models (Christensen et al., 2007). These models, however, do not agree on the sign of the future evolution of precipitation. Almost half of them predict an increase in rainfall and the other half a decrease (Vigaud et al., 2011; Berg et al., 2013), but changes could still be important (roughly ranging from -20 to $+20 \%$ in annual rainfall; see Sultan et al., 2013). More robust results have been reported regarding monthly anomalies of the rainy season in WA, with a delayed onset and offset and shortening of the rainy season (Biasutti and Sobel, 2009). Similar results are described in Patricola and Cook (2010).

\subsubsection{Changes in land use}

In recent decades WA has seen major changes in land use, with strong impacts on runoff (Wittig et al., 2007). For some rivers located in the Sahelian zone, discharge has increased, even with the drop in rainfall, because of considerable land use changes driven by demographic pressures. This is known as the Sahelian paradox (see, e.g., Mahe et al., 2005, for the Nakambe River). The extension of cropped areas combined with the shortening of fallow periods (Mortimore et al., 2005) has led to soil degradation and superficial crusting, thereby limiting infiltration and increasing runoff (Leblanc et al., 2008; Descroix et al., 2012).

\subsubsection{Changes in water consumption/withdrawals}

This factor may have an important impact on runoff in a region where the population is growing fast. For example, in WA water withdrawals have increased by $31 \%$ between 1983/1987 and 1998/2002 (Aquastat ${ }^{1}$ ). This value could increase much more in the future as food demand could quintuple by 2050 in the region (Collomb, 1999).

\subsubsection{Carbon effect on plant water use}

Rising $\mathrm{CO}_{2}$ concentration could alter vegetation water use (and thus the water cycle) through two opposite effects (Tubiello et al., 2007; Leakey, 2009; Alkama et al., 2010): (i) lower stomatal conductance which leads to a reduction in potential evapotranspiration (PET) and (ii) enhanced photosynthesis which leads to an increase in leaf area index and an increase in PET. Even though the effects of increased atmospheric $\mathrm{CO}_{2}$ levels on discharge remain highly uncertain, some global studies like Gerten et al. (2008) and Shi et al. (2011) have demonstrated that this carbon effect may have had a non-negligible impact on runoff.

\subsection{Database}

We collected all studies that have evaluated the effects of these major drivers on future runoff regimes in WA. Most studies have focused on the effects of climate variable changes. We constructed a database storing results of this latter effect. For this ensemble of projections - representing a wide variety of models, scenarios and methodologies - we quantify changes in runoff characteristics and the uncertainty therein. On the other hand, only few studies have addressed the other drivers of runoff change; therefore, results from these papers are not included in the database and are summarized herein in a more qualitative manner.

\footnotetext{
${ }^{1}$ http://www.fao.org/nr/water/aquastat/wateruse/index.stm
} 


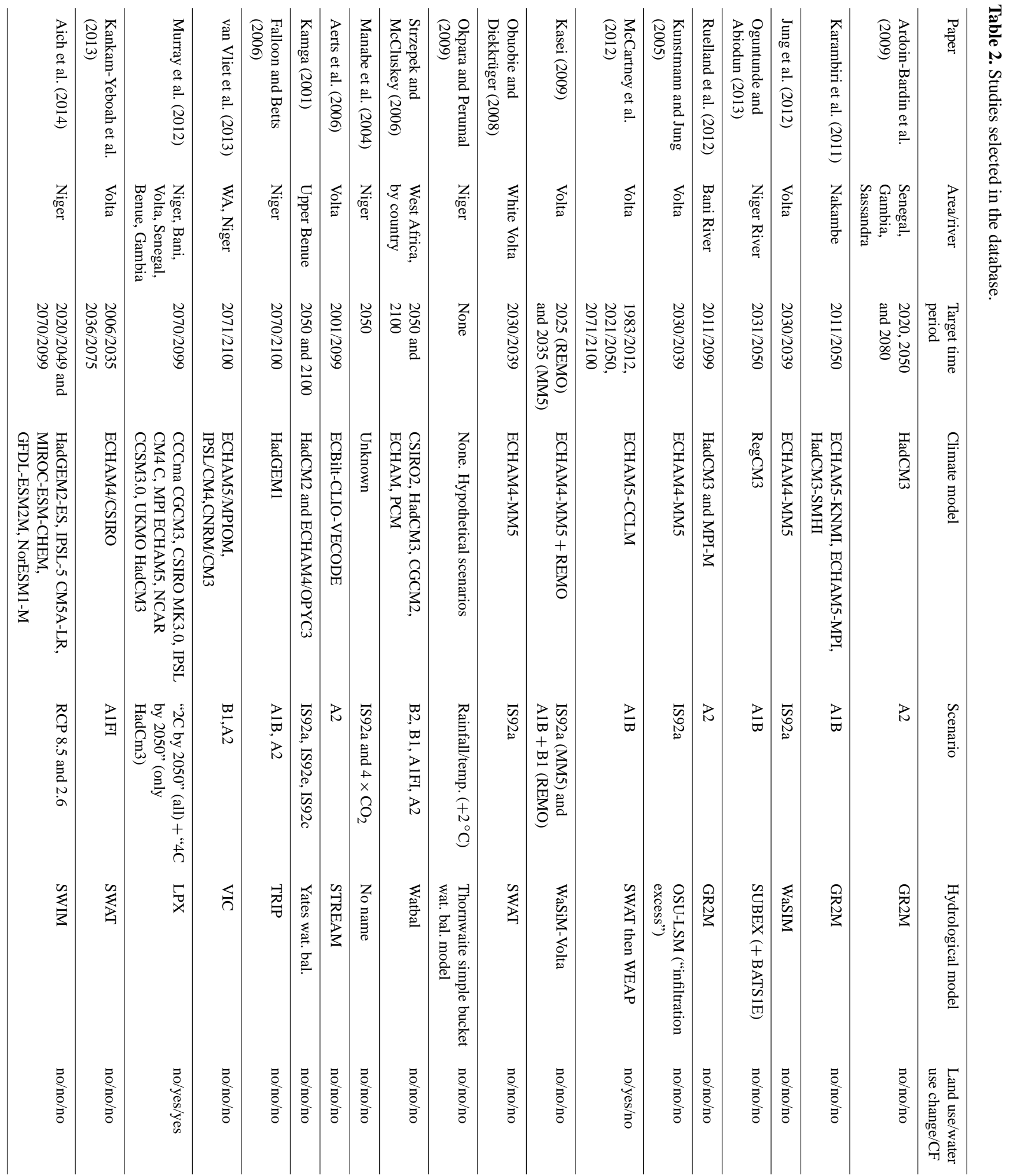


To create the database, we followed a methodology close to Roudier et al. (2011): we selected 16 peer-reviewed papers or conference proceedings, $1 \mathrm{PhD}$ thesis and 2 official reports published since 2000 that focus on runoff/discharge changes in WA (ECOWAS countries + Cameroon) in view of climate change only (Table 2). Milly et al. (2005) and Arnell (2004) were excluded from the database because it was not possible to access the detailed results at the river or regional scale or because they do not focus on the selected variables. These studies were however used in the discussion. The final database includes 301 runoff change values defined by different rivers, climate models, emission scenarios, time horizons and hydrological models.

Most studies used climate variables directly from general circulation models (GCMs) or regional circulation models (RCMs) that simulate climate variables using physical equations representing the circulation of the atmosphere and/or ocean. GCMs/RCMs can differ in terms of the conceptualization and parameterization of processes, as well as in their spatial resolution, which is typically circa $2.5^{\circ}$ for GCMs and $0.5^{\circ}$ for RCMs. To simulate the response of the global climate system to increasing greenhouse gas (GHG) concentrations, these models were forced by future GHG emission scenarios. Many different types of scenarios are available and are clustered in three main groups that were created in chronological order and used for the different IPCC reports: the early IS92 (Leggett et al., 1992) including for example scenario IS92a or IS92c; the SRES (Special Report on Emission Scenario; Nakicenovic and Swart, 2000) with, e.g., A1B, A2 or B1; and the RCPs (Representative Concentration Pathways; Moss et al., 2010) used in the IPCC Fifth Assessment Report (RCP 4.5, RCP 2.6, RCP 8.5). Each group is constituted by contrasted scenarios representing a low level of GHG emissions (e.g., for the SRES, scenario B1, which leads in 2100 to an average warming of $+1.9^{\circ} \mathrm{C}$ ) or high level (A2, which leads to $+3.1{ }^{\circ} \mathrm{C}$; see Meehl et al., 2007). The simulated climate variables were then used as inputs in an offline hydrological model (e.g., Falloon and Betts, 2006; Kamga, 2001). Some studies however did not use directly these climate models but made some assumptions about the future climate to generate potential time series (e.g., $+2{ }^{\circ} \mathrm{C}$ and $-5 \%$ for rainfall; Okpara and Perumal, 2009). Since such scenarios are within the range of potential evolutions simulated by the GCMs, we decided to include them in the database.

Furthermore, some works like McCartney et al. (2012) and Karambiri et al. (2011) included a downscaling step between the climate and hydrological model, through RCMs, a delta change approach (van Vliet et al., 2013) or a weather generator (Kankam-Yeboah et al., 2013). We chose in this review to put together all these methodologies, even if some of them are quite simple, rather than focusing on the most advanced ones, in order to give the best estimation of the uncertainty of the results.

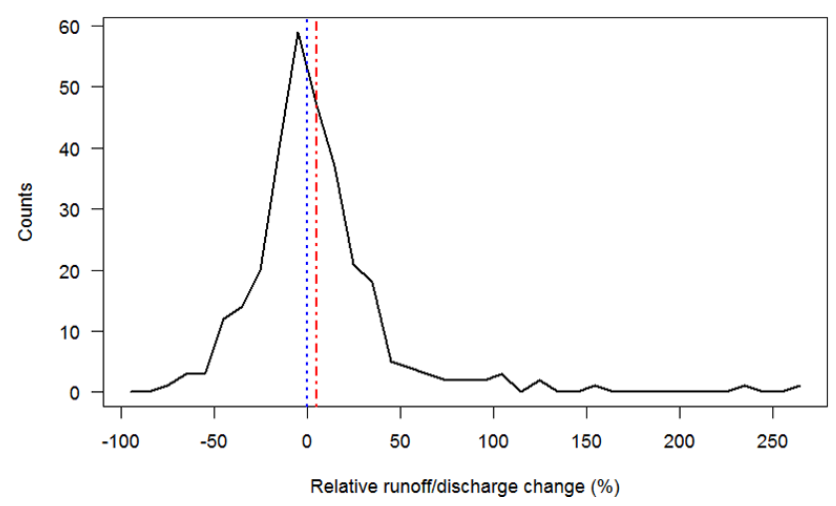

Figure 2. Runoff change ( $x$ axis, $\%$ ) in WA based on all cases in the database (i.e., including different time period, rivers and models). The blue dashed line represents the median of the distribution; the red one is the mean. We focus here only on the impact of climate change: this is the only changing parameter (no water use or land use change).

Concerning the other drivers of runoff change, McCartney et al. (2012) and Murray et al. (2012) used scenarios of water use change, Murray et al. (2012) dealt with the effects of increased atmospheric carbon concentration on runoff and no study accounted for land use dynamics. Note that to be consistent with the other studies dealing only with climate change, we did not put the results including water use and land use changes in the database, and thus we did not use them in Sects. 3.1 to 3.3. More precisely, for McCartney et al. (2012) and Murray et al. (2012), we only kept the "climate-only" scenario. The other scenarios were used in Sect. 3.4, as case studies.

\section{Results}

\subsection{Impact of climate change on yearly mean discharge}

\subsubsection{Over the whole region}

Even though the region is characterized by varying climatic and hydrological conditions, we first evaluated if a general climate signal could be detected in future streamflows across the whole study area. To do so, all the points contained in the database - representing different rivers, time periods and methods - were pooled and a distribution was constructed of the projected relative changes in mean annual river flows (i.e., $\left.\left(\left(Q_{\text {future }}-Q_{\text {present }}\right) / Q_{\text {present }}\right) \times 100\right)$. The latter is presented in Fig. 2, which depicts a high peak close to $0 \%$, expressed by the median $=0 \%$, the mean $=+5.2 \%$ and a very high range of potential future changes, from -100 to $+260 \%$. As discussed more in detail further herein, this is due to the use of different scenarios and models, but it also largely relates to the contrasted climatic zones of WA and the different projected climate changes therein. As almost 


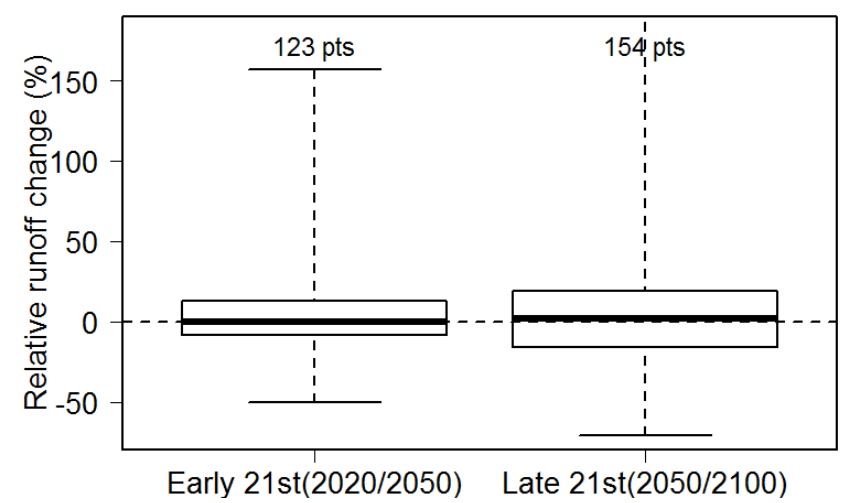

Figure 3. Impact of climate change on runoff at the beginning of the 21st century (left, 2020-2050) and at the end (right, 2050-2100).

$40 \%$ of the database is constituted by data from the World Bank study (Strzepek and McCluskey, 2006), we next randomly deleted $50 \%$ of this study's results in order to assess the robustness of our findings. We repeated this step 30 times and computed the resulting median. We did also the same experiment deleting $20 \%$ of the whole database. The results reveal that the median value found before is quite robust: it is indeed always (out of 60 tries) between -2 and $2 \%$.

The studies that were not contained in the database for reasons previously discussed do not agree either on the sign of runoff change in WA. Milly et al. (2005) found a slight negative trend and Paturel et al. (2007) concluded on a much more negative one, largely due to the use of a quite pessimistic scenario (PET $+5 \%$, rainfall $-10 \%$, doubling $\mathrm{CO}_{2}$ ). On the other hand, Arnell (2004) found that by 2055 in WA far fewer people would be affected by water stress, whereas Faramarzi et al. (2013) projected no change or a small increase in surface water and groundwater availability in most West African countries.

Figure 2 focuses on all points in the database, thereby mixing projections across different time horizons. To evaluate if the predicted impacts may be more pronounced by the end of the 21 st century because of rising greenhouse gas concentrations, we split the database into two parts based on the time horizon studied: early 21st (2020-2060) and late 21st century (2061-2100). Figure 3 shows that the selected future time period does not strongly influence the overall sign of future runoff evolution: the median for the early 21 st century is $0 \%$ and the median for the late 21 st century is $+2 \%$, but the difference is not significant. It is however important to note that both panels (early and late) do not include the same rivers, models or scenarios. The increase in interquartile range as time proceeds nevertheless suggests that signals of change become more pronounced with increasing greenhouse gas levels. This is also confirmed when evaluating the projections of individual studies that consider different time horizons. In $68 \%$ of the cases, the impact of climate is more evident in the late 21 st century, especially when the emission scenario
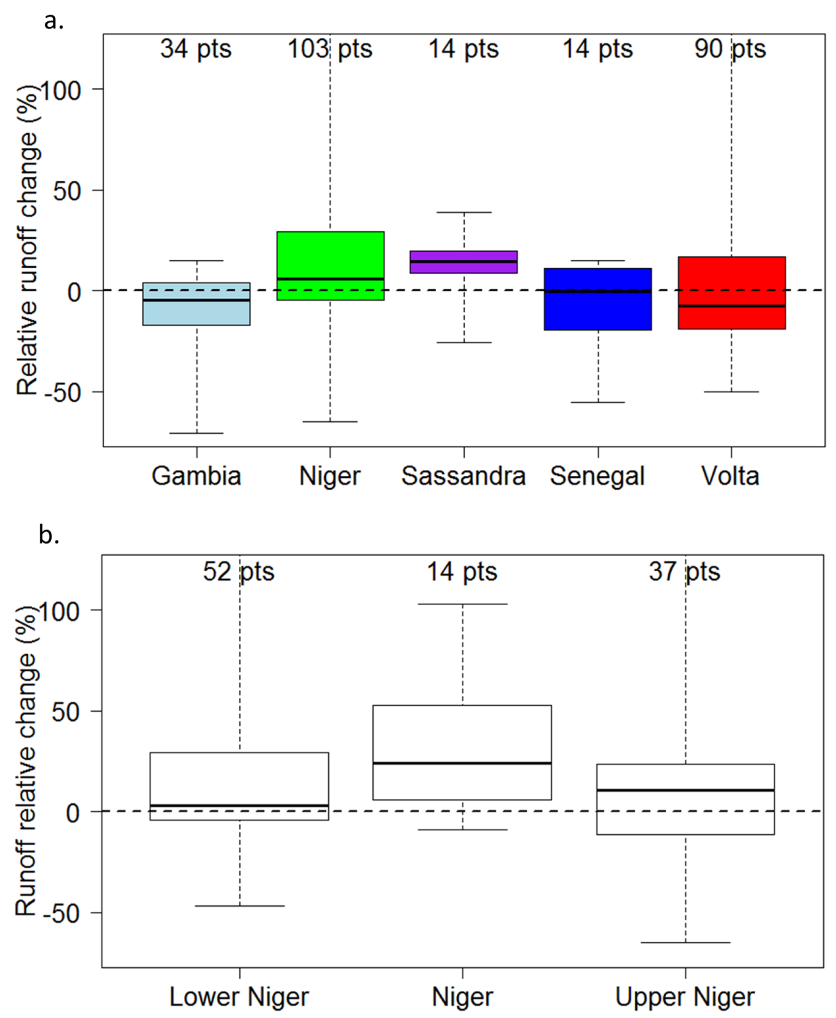

Figure 4. (a) Impact of climate change on runoff (\%), by river. Some previous clustering has been done (e.g., Bani and Benue are included with Niger and all the Volta tributaries are together). (b) Runoff relative change (\%) for different parts of the Niger River, according to the database. When only Niger is specified, this means that there is no description (upper or lower Niger) in the original paper.

taken into account has very contrasted radiative forcing between late and mid-century. Ruelland et al. (2012), for example, project a runoff evolution of $-5 \%$ by 2025 and $-65 \%$ by 2085 , using the SRES A2 scenario.

\subsubsection{Impact by river}

To evaluate projections in different regions of WA we clustered river basins or areas under the following labels: Niger is Niger, Bani and Benue; Volta is White Volta (or Nakambe), Black Volta, Burkina Faso (country using results of Strzepek and McCluskey, 2006) and Ghana (country). For the Senegal and Volta rivers, Fig. 4a shows that the median change is not statistically different from 0 , which means that the impact of climate change is small or not clear, even if it could potentially be very strong in some cases. For the Gambia River a small but significant negative trend is projected (median $=-4.5 \%$ ), whereas a positive significant evolution in river flows is projected for the Sassandra $(+14.4 \%)$ and the Niger rivers $(+6.1 \%)$. It is however important to note that the positive trend for the Niger River is mainly due to the study 


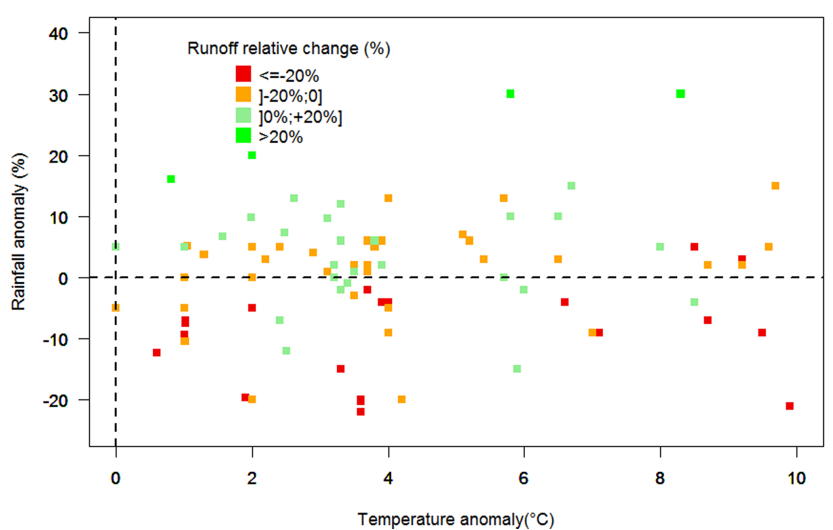

Figure 5. Rainfall ( $y$ axis) and temperature ( $x$ axis) anomalies associated with the runoff relative change (color scale). All the values come from the database.

by Aich et al. (2014), which represents $40 \%$ of the selected runoff changes.

We next focus on the heterogeneity of the results for the Niger River, which covers very different climatic zones (Fig. 1a) that may show dissimilar responses to climatic variations and future climate projections (e.g., lower temperature increase near the coasts). Thus, in order to detail more carefully the changes in the Niger River basin, we evaluate results separately for the lower Niger (i.e., the basin downstream Niamey and the Benue River), the upper Niger (Bani included) and the Niger River, representing the cases where only the Niger was quoted in the papers. Figure $4 \mathrm{~b}$ confirms that there is a wide range in the possible runoff evolutions even for a restricted part of the Niger River basin. Indeed, for the Bani River located in the upper part of the Niger basin, Murray et al. (2012) found a positive pattern in future streamflow that contradicts with the strong negative trend obtained by Ruelland et al. (2012). Moreover, there is no particular trend for the lower Niger, mainly due to papers on the Benue River, but a positive one is found for the Niger River, in its entirety as well as in its upper part. However, it is necessary to underline that, in a paper not included in the database, Paturel et al. (2007) projected the strongest negative river flow evolutions for the inner delta of Niger and the Fouta Djalon area. All these results show that future studies should focus more on the heterogeneity of the runoff change over the Niger basin.

\subsection{Relative role of rainfall and temperature in discharge evolution}

In this section we evaluate which parameters are the major drivers of the changes described in the previous section. We focus here on temperature, rainfall and PET, when the anomalies for these variables are available in the selected studies. Figure 5 shows the rainfall and temperature future changes associated with the runoff relative change.

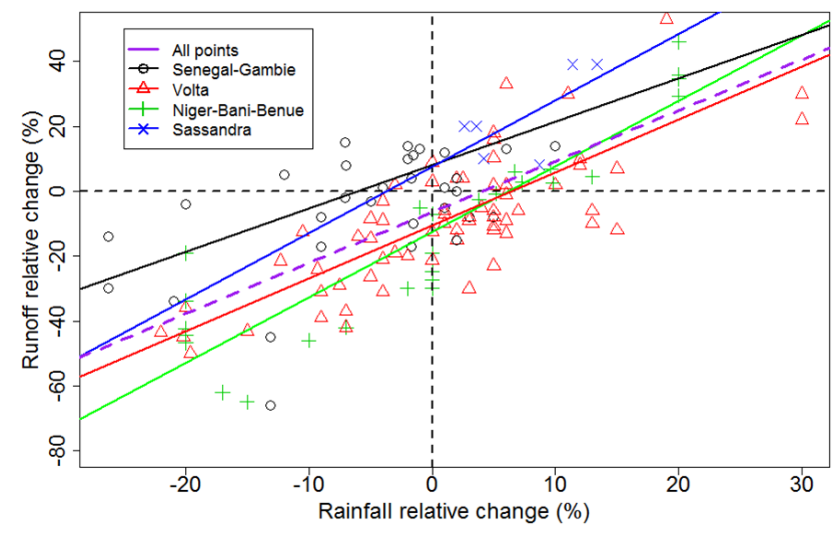

Figure 6. Relationship between runoff change ( $y$ axis, \%) and rainfall relative change ( $x$ axis, $\%$ ) for the four main rivers and for the whole panel (purple dashes). The lines represent the linear model for each river. Note that we put Senegal and Gambia together.

Qualitatively, this plot depicts a stronger effect of rainfall on runoff changes compared to temperature, with negative runoff values (orange and red) corresponding mainly to negative rainfall anomalies. This is confirmed by the Pearson correlation coefficients between changes in runoff and in the three variables. While rainfall is the dominating factor ( $R=0.49$, significant at $1 \%$ ) for river flow evolution, PET also plays an important, although opposite, role $(R=-0.35$, significant at $5 \%$ ). Although temperature indirectly affects streamflow through PET, no statistically significant relation ( $R=-0.04$, not significant) was found between the projected temperature and streamflow changes. These results are in accordance with earlier findings in the literature which underline the major role played by rainfall on future runoff changes (Kundzewicz et al., 2007) and its sensitivity to PET (UNECA and ACPC, 2011). Applying a similar correlation analysis, Murray et al. (2012) found similar results for rainfall $(R=0.53)$ for the Niger. The dominant role of rainfall for streamflow generation and the fact that projections of rainfall, especially with regard to the monsoon, remain to date highly uncertain (see Sect. 2.2) partly explain the contrasting results found among studies, depending on the chosen rainfall scenario.

To analyze the elasticity of runoff to precipitation (Guimberteau et al., 2013) in different parts of the area, we plot in Fig. 6 the future changes in runoff vs. those in rainfall for the four main rivers and for the whole area. The variation in steepness of the fitted linear regression lines shows that rivers in WA react differently to the same drop or increase in rainfall (Table 3). The highest sensitivity to rainfall changes is found in the Niger and Sassandra rivers, although for the latter basin data points are only available for positive changes in precipitation. Aich et al. (2014), doing the same kind of analysis for the Niger but with annual values, found an even stronger sensitivity to rainfall: according to their study, $a+25 \%$ increase in rainfall would lead to a 
Table 3. Regression equation between rainfall change and runoff change, for each of the river.

\begin{tabular}{llc}
\hline River & Equation & $\begin{array}{c}\text { Pearson } \\
\text { correlation } \\
\text { coefficient }\end{array}$ \\
\hline Senegal-Gambia & Runoff change $=1.3 \times$ rainfall change +8.0 & 0.59 \\
Volta & Runoff change $=1.6 \times$ rainfall change -10.6 & 0.77 \\
Niger-Bani-Banue & Runoff change $=2.0 \times$ rainfall change -12.6 & 0.91 \\
Sassandra & Runoff change $=2.0 \times$ rainfall change +7.7 & 0.68 \\
All & Runoff change $=1.6 \times$ rainfall change -6.5 & 0.73 \\
\hline
\end{tabular}

\begin{tabular}{|c|c|c|c|c|c|c|c|c|c|c|c|c|c|}
\hline River & Paper & j & $f$ & $\mathbf{m}$ & a & m & $\mathrm{j}$ & $\mathrm{j}$ & a & $s$ & 0 & $\mathbf{n}$ & d \\
\hline \multirow[t]{2}{*}{$\underline{\text { Volta }}$} & Jung et al. 2012 & & & & & & & & & & & & \\
\hline & $\begin{array}{l}\text { Kunstmann \& Jung } \\
2005\end{array}$ & & & & & & & & & & & & \\
\hline \multirow[t]{2}{*}{$\underline{\text { Senegal }}$} & $\begin{array}{l}\text { Ardoin-Bardin et al. } \\
2009 \text { (for 2080) }\end{array}$ & & & & & & & & & & & & \\
\hline & Murray et al., 2012 & & & & & & & & & & & & \\
\hline Benue & Kamga, 2001, IS92C & & & & & & & & & & & & \\
\hline Bani & $\begin{array}{l}\text { Ruelland et al., } 2012 \\
\text { (HadCM3, 2055) }\end{array}$ & & & & & & & & & & & & \\
\hline \multirow[t]{4}{*}{ Niger } & Fallon \& Betts, 2006 & & & & & & & & & & & & \\
\hline & Van Vliet et al, 2013 & & & & & & & & & & & & \\
\hline & $\begin{array}{l}\text { Okpara \& Perumal, } \\
2009\end{array}$ & & & & & & & & & & & & \\
\hline & $\begin{array}{l}\text { Oguntunde \& Abiodun } \\
2012\end{array}$ & & & & & & & & & & & & \\
\hline$\frac{\text { Lower }}{\text { Niger }}$ & Murray et al., 2012 & & & & & & & & & & & & \\
\hline Sassandra & $\begin{array}{l}\text { Ardoin-Bardin et al., } \\
2009 \text { (for 2080) }\end{array}$ & & & & & & & & & & & & \\
\hline Gambia & $\begin{array}{l}\text { Ardoin-Bardin et al., } \\
2009 \text { (for 2080) }\end{array}$ & & & & & & & & & & & & \\
\hline
\end{tabular}

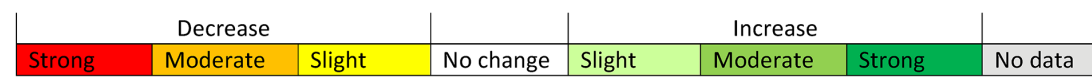

Figure 7. Qualitative assessment of monthly runoff relative change, for different studies of the database and for different rivers. The assessment may be an interpretation of the paper's results (see Table 4 for more details about each paper results). In some cases we only detailed here one time horizon or one climate model.

$+90 \%$ increase in runoff. The lowest sensitivity is found for Senegal/Gambia, but the underlying values come from only one study. The fitted lines do not intersect the $y$ axis at zero but at different points along the $y$ axis. If this were the case, this would imply no change in river runoff for no change in rainfall. Here, however, this shift is related to catchmentspecific sensitivities of runoff to changes in PET and $T$ as well as to uncertainties in the hydrological model in translating climate inputs to runoff. These effects that are not caused by rainfall changes seem strongest for the Niger and Volta rivers (circa $-12 \%$; close to Aich et al., 2014, for the Niger River). Their overall impact is about $-8 \%$ taking all rivers and warming scenarios into account, and a $10 \%$ drop in rainfall would result in a reduction in river flow of approximately $25 \%$.

\subsection{Impacts of climate change on intra-annual variability and extremes}

Most studies contained in the database focus solely on annual discharges. Some studies, however, also detailed the impacts of future climate on monthly values and extreme river flows. We summarized the results for each river and present a qualitative assessment in Fig. 7 and Table 4. To date, only McCartney et al. (2012) have focused in WA on the potential effect of climate change on the magnitude of floods for a range of return periods. By the end of this century, the magnitude of frequent floods (with return periods less than 10 years) is projected to decrease in the Volta River, whereas the trend for higher return period floods (i.e., more extreme) is not consistent from station to station. Moreover, Jung et al. (2012) and Kunstmann and Jung (2005) found an increase in runoff in September, when flows in the Volta are typically the highest (Fig. 1b). For the Senegal, Gambia and Sassandra rivers, on the other hand, high flows (September and October) are projected to decrease (Ardoin-Bardin et al., 
Table 4. Impact of future climate on monthly runoff and on floods/droughts, according to the papers selected in the database.

\begin{tabular}{|c|c|}
\hline River & Changes \\
\hline Volta & $\begin{array}{l}\text { - The magnitude of low return period (i.e., frequent) floods decreases in } 2035 \text { and } 2085 \text { in all sub-basins. } \\
\text { For higher return period floods, it depends (McCartney et al., 2012). } \\
\text { - Streamflow increases in Sep-Oct (around 20\%), decrease in Jul-Aug (about -10\%) (Jung et al., 2012). } \\
\text { - Higher runoff values in May-Jun and Aug-Sep but lower in July (Kunstmann and Jung, 2005). }\end{array}$ \\
\hline Senegal/Gambia & $\begin{array}{l}\text { - At the } 2080 \text { horizon, the peak flows in September show a decrease for the Senegal }(-27 \%) \text { and Gambia } \\
(-37 \%) \text { catchments (Ardoin-Bardin et al., 2009). } \\
\text { - According to global maps (Murray et al., 2012), in some parts of Senegal and Gambia, the month of } \\
\text { maximum runoff is delayed by } 1 \text { month, with no strong change of minimum runoff. }\end{array}$ \\
\hline Niger/Bani/Benue & $\begin{array}{l}\text { - Similar pattern (month by month) but higher peak flows in Sep-Oct and slightly lower in Jul-Aug } \\
\text { (Kamga, } 2001 \text { for Benue River). } \\
\text { - A later occurrence of the flows and an earlier start of the depletion phase (Ruelland et al., 2012, for the } \\
\text { Bani River.) } \\
\text { - Changes in maximum monthly river flow: A1B: }+105 \% \text {; A2: }+137 \% \text {. Peak flow is } 1 \text { month later for } \\
\text { scenario A2, no change for A1B (Falloon and Betts, } 2006 \text {, Niger). } \\
--1 \% \text { for low flows and }+11 \% \text { for high flows (van Vliet et al., } 2013 \text {, for the Niger River) } \\
\text { - According to global maps (Murray et al., 2012), in the Niger delta and the Niger loop, the month of } \\
\text { maximum runoff is } 1 \text { month delayed, with no strong change of minimum runoff. } \\
\text { - For Aich et al. (2014), high flows }\left(Q_{10}\right) \text { and especially low flows }\left(Q_{90}\right) \text { are generally expected to increase. }\end{array}$ \\
\hline Sassandra & $\begin{array}{l}\text { Simulated flows for June to August are greater than observed flows and partly offset the decrease in } \\
\text { runoff in September-October in } 2080(-22 \%) \text { (Ardoin-Bardin et al., 2009). }\end{array}$ \\
\hline
\end{tabular}

2009). On the Niger River, results depend on the area studied, but some agreements seem to arise on (i) a later occurrence of the peak flows (Murray et al., 2012; Falloon and Betts, 2006) and (ii) an increase of peak flows (Kamga, 2001; van Vliet et al., 2013; Falloon and Betts, 2006). However, this is only a global pattern. As underlined by Aich et al. (2014), the results strongly depend on the climate model used and also on the area. On the Bani River, which is a tributary of the Niger, Ruelland et al. (2012) found indeed a strong decrease in maximum monthly runoff. These findings show that there is currently insufficient information to make strong statements about possible evolutions in West African hydrographs, although any such changes would be a major concern for flood protection, dam design or socio-economic activities depending on water availability (Roudier and Mahé, 2010).

\subsection{Impact of climate change vs. other factors}

As underlined in Sect. 2, other drivers also affect runoff generation. These include the effect of increased atmospheric carbon concentrations on plant water use efficiency (WUE) and leaf area index, intensive water use and anthropogenic land use changes. In this section we evaluate to what extent these other drivers control discharge, and whether their impact is negligible, or not, compared to climate. Several works have looked at the marginal effects of these drivers on river flow in other regions of the world, but only very few studies have addressed these issues in WA, resulting in only few data points being contained in the database (two studies accounted for water consumption, one for the carbon effect and none for land use dynamics).

\subsubsection{Carbon effect and water consumption}

McCartney et al. (2012) designed four different scenarios of water consumption, whereas Murray et al. (2012) accounted for the effects of water withdrawals and of atmospheric carbon increase. Both studies underlined the potential of these drivers in altering streamflows, but the changes they induce are generally less important than the effects of climate change. McCartney et al. (2012) found an average impact of climate change on runoff of $-34 \%$ without water use changes and $-43 \%$ with the full-development scenario. Similarly, Fig. 8a, which summarizes the results of Murray et al. (2012), shows that the effects of water withdrawals on future runoff can be considerable but do not reverse the climate signal. Moreover, the effect of carbon on runoff depicted in Fig. $8 \mathrm{~b}$ seems to be smaller than that of water withdrawal changes. In WA as a whole, the median change under the scenario with fixed carbon concentration amounts to $+31.6 \%$ while $a+30.3 \%$ increase in runoff is projected when the increase in carbon concentration is accounted for. However, as underlined by Murray et al. (2012), the effect of higher carbon concentration on runoff is very different across WA: it can indeed cause a decrease (e.g., Benue River) or an increase (Sassandra) in river discharge. These results are consistent with past trends at the global scale on the relative share of land use, water consumption/withdrawal, climate 

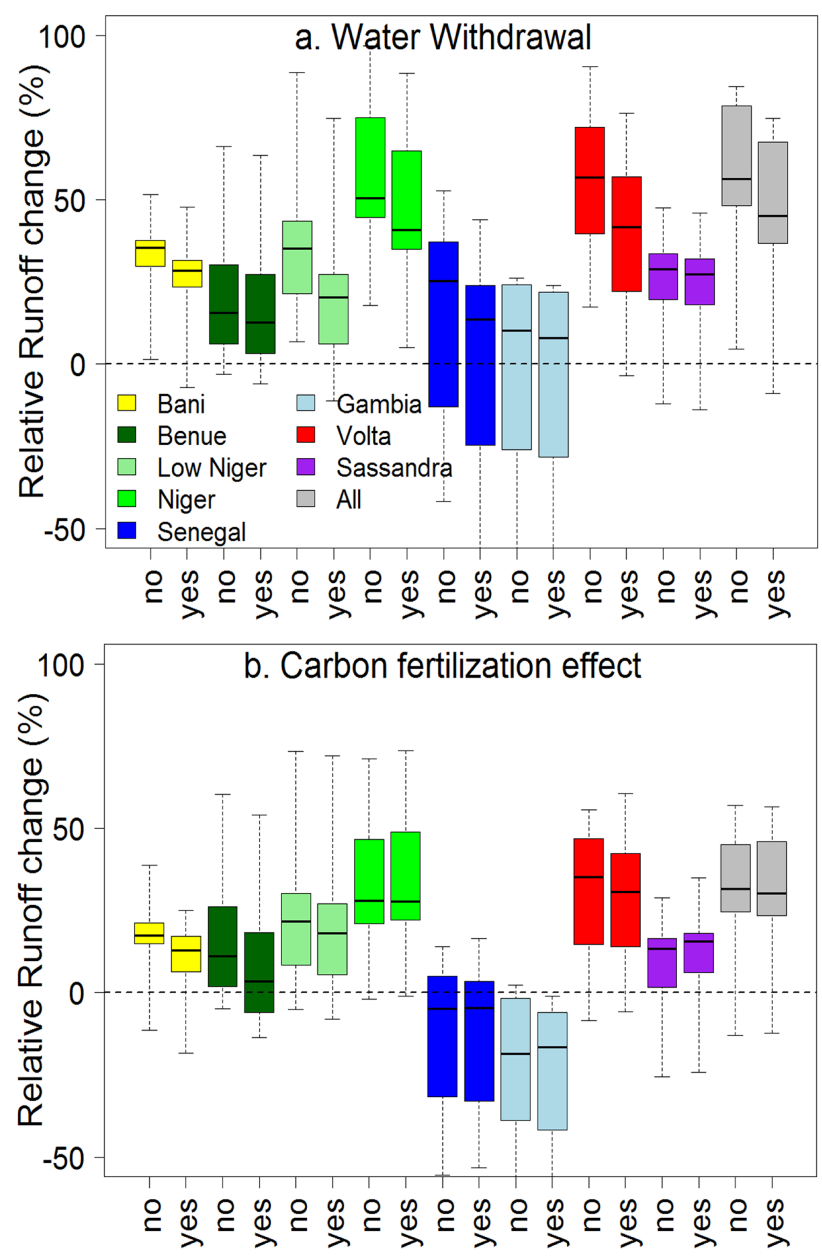

Figure 8. (a) Impact of future water withdrawals on runoff relative change (\%) for 8 rivers. (b) Runoff relative change (\%) for 8 rivers and 2 different scenarios: (i) taking higher carbon concentration into account ("Yes") and (ii) with fixed carbon concentration ("No"). Values are from Murray et al. (2012).

and carbon effect on retrospective runoff changes (Sterling et al., 2013).

\subsubsection{Land use changes}

Gerbaux et al. (2009) for the Sahelian area and Sterling et al. (2013) at the global scale have demonstrated that anthropogenic land use dynamics have been more important than, or equally important to, climate change in past runoff evolution. These studies illustrate the very important role of land use changes on hydrology. Despite this potential strong impact, we found only three studies that we did not include in the database dealing with this issue. Oguntunde et al. (2012) showed that for scenarios including future climate change and hypothetical levels of reforestation in the Niger basin, runoff would significantly increase compared to a "climate only" scenario. Meigh et al. (2005), on the other hand, found almost no change when including land use in their analysis in WA. Finally, Cornelissen et al. (2013), using several contrasted scenarios of future land use changes in Benin, found that such modifications could have a substantial impact on discharge. However, it strongly depends on the hydrological model used. Further studies using socio-economic-based land use change scenarios are thus needed in order to assess precisely the role of land use in future discharge changes in WA.

\section{Conclusions}

To summarize the current state of knowledge on potential future streamflow evolutions in view of global warming in West Africa, we created from all relevant available studies a database of 301 points containing quantitative information on the impact of climate change on runoff in the region. We found that there is no clear general pattern of future runoff evolution in this area (the median of the distribution is $0 \%$ and the mean $+5.2 \%$, considering different time horizons, different rivers, scenarios and models) but that potential changes could be very large in some rivers. The future tendency is still very uncertain when looking at river basins separately, except for the Gambia River, which exhibits a significant negative change (median $=-4.5 \%)$. For the Sassandra and the Niger rivers, however, the change is positive $(+14.4 \%$ for Sassandra, $+6.1 \%$ for Niger) but still with a large range of potential changes. The high variability in projections is due to the large area of the river basins and to very contrasted rainfall changes predicted by the climate models, roughly from $-20 \%$ to $+20 \%$ on average over West Africa. Correlation analysis revealed that runoff changes are tightly linked to changes in rainfall $(R=0.49)$, whereas PET is also significantly correlated to runoff. Only few studies have focused-on-month by month runoff evolution; that is why it is hard to find robust results on changes in intra-annual variability. However, the maximum monthly river flow of the Niger River could increase in the future and the peak flow could be delayed.

We also studied other factors influencing runoff such as land use, water consumption and the effect of higher carbon concentration. Based on two studies, our results showed that the carbon effect as well as water withdrawals can potentially have significant impacts on runoff changes, but they generally do not offset the effect of climate change. Although land use changes have played a major role in past runoff evolution in West Africa, only two studies have dealt with this issue, with contrasting results. One study stated that the difference between "climate-only" and "climate with land use changes" scenarios could be significant, whereas the other found very minor changes.

This review shows the need for more studies on the assessment of future water resources in West Africa. Despite the general agreement about the high vulnerability of this 
area to climate change, there is a real lack of studies focusing on this region. Future studies should look more in detail to high and low flow variations, which are fundamental for agriculture, fisheries and dams. There is also an urgent need to take into account the other factors influencing runoff, especially water and land use changes, in order to get a more comprehensive assessment and to guide the elaboration of sound adaptation strategies. This can be achieved through the use of integrated process-based models that simultaneously include the driving processes that link climate, carbon, water and terrestrial vegetation dynamics (Guimberteau et al., 2014; Gerten, 2013).

Acknowledgements. We would like to thank all the authors of papers included in the database, especially Steve Murray and Valentin Aich for their help. We thank also four reviewers for their valuable comments.

Edited by: D. Mazvimavi

\section{References}

Aerts, J. C. J. H., Renssen, H., Ward, P. J., De Moel, H., Odada, E., Bouwer, L. M., and Goosse, H.: Sensitivity of global river discharges under Holocene and future climate conditions, Geophys. Res. Lett., 33, L19401, doi:10.1029/2006GL027493, 2006.

Aich, V., Liersch, S., Vetter, T., Huang, S., Tecklenburg, J., Hoffmann, P., Koch, H., Fournet, S., Krysanova, V., Müller, E. N., and Hattermann, F. F.: Comparing impacts of climate change on streamflow in four large African river basins, Hydrol. Earth Syst. Sci., 18, 1305-1321, doi:10.5194/hess-18-1305-2014, 2014.

Alkama, R., Kageyama, M., and Ramstein, G.: Relative contributions of climate change, stomatal closure, and leaf area index changes to 20th and 21st century runoff change: A modelling approach using the Organizing Carbon and Hydrology in Dynamic Ecosystems (ORCHIDEE) land surface model, J. Geophys. Res.Atmos., 115, D17112, doi:10.1029/2009jd013408, 2010.

Ardoin-Bardin, S., Dezetter, A., Servat, E., Paturel, J. E., Mahé, G., Niel, H., and Dieulin, C.: Using general circulation model outputs to assess impacts of climate change on runoff for large hydrological catchments in West Africa, Hydrolog. Sci. J., 54, 77-89, doi:10.1623/hysj.54.1.77, 2009.

Arnell, N. W.: Climate change and global water resources: SRES emissions and socio-economic scenarios, Global Environ. Change, 14, 31-52, doi:10.1016/j.gloenvcha.2003.10.006, 2004.

Bélières, J.-F., Hilhorst, T., Kébé, D., Keïta, M. S., Keïta, S., and Sanogo, O.: Irrigation et pauvreté: le cas de l'Office du Niger au Mali, Cahiers Agricultures, 20, 144-149, 2011.

Berg, A., de Noblet-Ducoudré, N., Sultan, B., Lengaigne, M., and Guimberteau, M.: Projections of climate change impacts on potential C4 crop productivity over tropical regions, Agr. Forest Meteorol., 170, 89-102, doi:10.1016/j.agrformet.2011.12.003, 2013.

Biasutti, M. and Sobel, A. H.: Delayed Sahel rainfall and global seasonal cycle in a warmer climate, Geophys. Res. Lett., 36, L23707, doi:10.1029/2009g1041303, 2009.
Christensen, J. H., Hewitson, B., Busuioc, A., Chen, A., Gao, X., Held, I., Jones, R., Kolli, R. K., Kwon, W.-T., Laprise, R., Magaña Rueda, V., Mearns, L., Menéndez, C. G., Räisänen, J., Rinke, A., Sarr, A., and Whetton, P.: Regional Climate Projections, in: Climate Change 2007: The Physical Science Basis, Contribution of Working Group I to the Fourth Assessment Report of the Intergovernmental Panel on Climate Change, edited by: Solomon, S., Qin, D., Manning, M., Chen, Z., Marquis, M., Averyt, K. B., Tignor, M., and Miller, H. L., Cambridge University Press, Cambridge, UK and New York, NY, USA, 2007.

Collomb, P.: Une voie étroite pour la sécurité alimentaire d'ici à 2050, edited by: Economica-FAO, Economica-FAO, Rome, Paris, 1999.

Cornelissen, T., Diekkrüger, B., and Giertz, S.: A comparison of hydrological models for assessing the impact of land use and climate change on discharge in a tropical catchment, J. Hydrol., 498, 221-236, 2013.

Descroix, L., Genthon, P., Amogu, O., Rajot, J.-L., Sighomnou, D., and Vauclin, M.: Change in Sahelian Rivers hydrograph: The case of recent red floods of the Niger River in the Niamey region, Global Planet. Change, 98-99, 18-30, doi:10.1016/j.gloplacha.2012.07.009, 2012.

Descroix, L., Moussa, I. B., Genthon, P., Sighomnou, D., Mahé, G., Mamadou, I., Vandervaere, J.-P., Gautier, E., Maiga, O. F., Rajot, J.-L., Abdou, M. M., Dessay, N., Ingatan, A., Noma, I., Yéro, K. S., Karambiri, H., Fensholt, R., Albergel, J., and Olivry, J.-C.: Impact of Drought and Land - Use Changes on Surface - Water Quality and Quantity: The Sahelian Paradox, Curr. Perspect. Contam. Hydrol. Water Res. Sustain., in: Current Perspectives in Contaminant Hydrology and Water Resources Sustainability, chap. 10, edited by: Bradley, P. M., 243-271, doi:10.5772/54536, 2013.

ENDA-TM: Climate change adaptation and water resources management in west Africa, Synthesis report, WRITESHOP, Dakar, Senegal, 95 pp., 2007.

Falloon, P. D. and Betts, R. A.: The impact of climate change on global river flow in HadGEM1 simulations, Atmos. Sci. Lett., 7, 62-68, 2006.

FAO: Sahel: situation meteorologique et etat des cultures, Rapport du 11 juin 2004, http://www.fao.org/docrep/006/j2517f/ j2517f00.HTM (last access: July 2014), 2004.

Faramarzi, M., Abbaspour, K. C., Ashraf Vaghefi, S., Farzaneh, M. R., Zehnder, A. J. B., Srinivasan, R., and Yang, H.: Modeling impacts of climate change on freshwater availability in Africa, $\mathbf{J}$ Hydrol., 480, 85-101, doi:10.1016/j.jhydrol.2012.12.016, 2013.

Gerbaux, M., Hall, N., Dessay, N., and Zin, I.: The sensitivity of Sahelian runoff to climate change, Hydrolog. Sci. J., 54, 5-16, 2009.

Gerten, D.: A vital link: water and vegetation in the Anthropocene, Hydrol. Earth Syst. Sci., 17, 3841-3852, doi:10.5194/hess-173841-2013, 2013.

Gerten, D., Rost, S., von Bloh, W., and Lucht, W.: Causes of change in 20th century global river discharge, Geophys. Res. Lett., 35, L20405, doi:10.1029/2008GL035258, 2008.

Global Runoff Data Centre: Long-Term Mean Monthly Discharges and Annual Characteristics of GRDC Station/Global Runoff Data Centre, Federal Institute of Hydrology (BfG), Koblenz, Germany, 2011. 
Guimberteau, M., Ronchail, J., Espinoza, J., Lengaigne, M., Sultan, B., Polcher, J., Drapeau, G., Guyot, J., Ducharne, A., and Ciais, P.: Future changes in precipitation and impacts on seasonal extreme streamflows over Amazonian sub-basins, Environ. Res. Lett., 8, 14-35, doi:10.1088/1748-9326/8/1/014035, 2013.

Guimberteau, M., Ducharne, A., Ciais, P., Boisier, J. P., Peng, S., De Weirdt, M., and Verbeeck, H.: Testing conceptual and physically based soil hydrology schemes against observations for the Amazon Basin, Geosci. Model Dev., 7, 1115-1136, doi:10.5194/gmd7-1115-2014, 2014.

Jung, G., Wagner, S., and Kunstmann, H.: Joint climate-hydrology modeling: An impact study for the data-sparse environment of the Volta Basin in West Africa, Hydrol. Res., 43, 231-248, 2012.

Kamga, F.: Impact of greenhouse gas induced climate change on the runoff of the Upper Benue River (Cameroon), J. Hydrol., 252, 145-156, doi:10.1016/S0022-1694(01)00445-0, 2001.

Kankam-Yeboah, K., Obuobie, E., Amisigo, B., and OpokuAnkomah, B.: Impact of climate change on streamflow in selected river basins in Ghana, Hydrolog. Sci. J., 58, 773-788, doi:10.1080/02626667.2013.782101, 2013.

Karambiri, H., García Galiano, S. G., Giraldo, J. D., Yacouba, H., Ibrahim, B., Barbier, B., and Polcher, J.: Assessing the impact of climate variability and climate change on runoff in West Africa: the case of Senegal and Nakambe River basins, Atmos. Sci. Lett., 12, 109-115, doi:10.1002/asl.317, 2011.

Kasei, R.: Modelling impacts of climate change on water resources in the Volta Basin, West Africa, PhD, MathematischNaturwissenschaftlichen Fakultät, Rheinischen FriedrichWilhelms-Universität Bonn, Bonn, Germany, 195 pp., 2009.

Kundzewicz, Z. W., Mata, L. J., Arnell, N. W., Döll, P., Kabat, P., Jiménez, B., Miller, K. A., Oki, T., Sen, Z., and Shiklomanov, I. A.: Freshwater resources and their management, in: Climate Change 2007: Impacts, Adaptation and Vulnerability. Contribution of Working Group II to the Fourth Assessment Report of the Intergovernmental Panel on Climate Change, edited by: Parry, M. L., Canziani, O. F., Palutikof, J. P., van der Linden, P. J., and Hanson, C. E., Cambridge University Press, Cambridge, UK, $173-210,2007$.

Kunstmann, H. and Jung, G.: Impact of regional climate change on water availability in the Volta basin of West Africa, Seventh IAHS Scientific Assembly, Foz do Iguaçu, Brazil, 2005,

Leakey, A. D. B.: Rising atmospheric carbon dioxide concentration and the future of $\mathrm{C} 4$ crops for food and fuel, Proceedings of the Royal Society B: Biological Sciences, 276, 2333-2343, 2009.

Lebel, T. and Ali, A.: Recent trends in the Central and Western Sahel rainfall regime (1990-2007), J. Hydrol., 375, 52-64, doi:10.1016/j.jhydrol.2008.11.030, 2009.

Leblanc, M. J., Favreau, G., Massuel, S., Tweed, S. O., Loireau, M., and Cappelaere, B.: Land clearance and hydrological change in the Sahel: SW Niger, Global Planet. Change, 61, 135-150, doi:10.1016/j.gloplacha.2007.08.011, 2008.

Leggett, J., Pepper, W. J., Swart, R. J., Edmonds, J., Filho, L. G. M., Mintzer, I., Wang, M. X., and Watson, J.: Emissions Scenarios for the IPCC: an Update, in: Climate Change 1992: The Supplementary Report to The IPCC Scientific Assessment, Cambridge University Press, Cambridge, UK, 68-95, 1992.
Mahe, G., Paturel, J.-E., Servat, E., Conway, D., and Dezetter, A.: The impact of land use change on soil water holding capacity and river flow modelling in the Nakambe River, Burkina-Faso, J. Hydrol., 300, 33-43, doi:10.1016/j.jhydrol.2004.04.028, 2005.

Mahe, G., Lienou, G., Descroix, L., Bamba, F., Paturel, J. E., Laraque, A., Meddi, M., Habaieb, H., Adeaga, O., Dieulin, C., Chahnez Kotti, F., and Khomsi, K.: The rivers of Africa: witness of climate change and human impact on the environment, Hydrol. Process., 27, 2105-2114, doi:10.1002/hyp.9813, 2013.

Manabe, S., Milly, P. C. D., and Wetherald, R.: Simulated long-term changes in river discharge and soil moisture due to global warming/Simulations à long terme de changements d'écoulement fluvial et d'humidité du sol causés par le réchauffement global, Hydrolog. Sci. J., 49, 625-642, doi:10.1623/hysj.49.4.625.54429, 2004.

McCartney, M., Forkuor, G., Sood, A., Amisigo, B., Hattermann, F., and Muthuwatta, L.: The water resource implications of changing climate in the Volta River Basin, IWMI Research Report 146, International Water Colombo, Sri Lanka, doi:10.5337/2012.219, 2012.

Meehl, G. A., Stocker, T. F., Collins, W. D., Friedlingstein, P., Gaye, A. T., Gregory, J. M., Kitoh, A., Knutti, R., Murphy, J. M., Noda, A., Raper, S. C. B., Watterson, I. G., Weaver, A. J., and Zhao, Z.C.: Global Climate Projections, in: Climate Change 2007: The Physical Science Basis.Contribution of Working Group I to the Fourth Assessment Report of the Intergovernmental Panel on Climate Change, edited by: Solomon, S., Qin, D., Manning, M., Chen, Z., Marquis, M., Averyt, K. B., Tignor, M., and Miller, H. L., Cambridge University Press, Cambridge, UK and New York, NY, USA., 2007.

Meigh, J., Folwell, S., and Sullivan, C.: Linking water resources and global change in West Africa: Options for assessment, Seventh IAHS scientific assembly, Foz do Iguaçu, Brazil, 297-306, 2005.

Milly, P. C. D., Dunne, K. A., and Vecchia, A. V.: Global pattern of trends in streamflow and water availability in a changing climate, Nature, 438, 347-350, 2005.

Mitchell, T. D. and Jones, P. D.: An improved method of constructing a database of monthly climate observations and associated high-resolution grids, Int. J. Climatol., 25, 693-712, 2005.

Mortimore, M., Ba, M., Mahamane, A., Rostom, R. S., Serra del Pozo, P., and Turner, B.: Changing systems and changing landscapes: Measuring and interpreting land use transformation in African drylands, Geografisk Tidsskrift, 105, 101-118, 2005.

Moss, R. H., Edmonds, J. A., Hibbard, K. A., Manning, M. R., Rose, S. K., van Vuuren, D. P., Carter, T. R., Emori, S., Kainuma, M., Kram, T., Meehl, G. A., Mitchell, J. F. B., Nakicenovic, N., Riahi, K., Smith, S. J., Stouffer, R. J., Thomson, A. M., Weyant, J. P., and Wilbanks, T. J.: The next generation of scenarios for climate change research and assessment, Nature, 463, 747-756, 2010.

Murray, S. J., Foster, P. N., and Prentice, I. C.: Future global water resources with respect to climate change and water withdrawals as estimated by a dynamic global vegetation model, J. Hydrol., 448-449, 14-29, 2012.

Nakicenovic, N. and Swart, R.: Special Report on Emissions Scenarios, edited by: Nakicenovic, N. and Swar, R., Cambridge University Press, Cambridge, UK, 612 pp., 2000.

Neiland, A. and Béné, C.: Review of River Fisheries Valuation in West and Central Africa, WorldFish Center, Penang, Malaysia, 2008. 
Obuobie, E. L. and Diekkrüger, B.: Using SWAT to Evaluate Climate Change Impact on Water Resources in the White Volta River Basin, West Africa, Conference on International Research on Food Security, Natural Resource Management and Rural Development, Hohenheim, Germany, 2008.

Oguntunde, P. G. and Abiodun, B. J.: The impact of climate change on the Niger River Basin hydroclimatology, West Africa, Clim. Dynam., 40, 81-94, 2013.

Oguntunde, P. G., Abiodun, B. J., Lischeid, G., and Merz, C.: Modelling the impacts of reforestation on the projected hydroclimatology of Niger River Basin, West Africa, Ecohydrology, 7, 163176, doi:10.1002/eco.1343, 2012.

Okpara, J. N. and Perumal, M.: Hydroinformatics in hydrology, hydrogeology and water resources, edited by: Cluckie, I. D., Chen, Y., Babovic, V., Konikow, L., Mynett, A., Demuth, S., and Savic, D. A., Proceedings of Symposium JS.4 at the Joint Convention of the International Association of Hydrological Sciences (IAHS) and the International Association of Hydrogeologists (IAH) held in Hyderabad, India, 6-12 September 2009, 58-71, 2009.

Patricola, C. and Cook, K.: Northern African climate at the end of the twenty-first century: an integrated application of regional and global climate models, Clim. Dynam., 35, 193-212, doi:10.1007/s00382-009-0623-7, 2010.

Paturel, J. E., Ouedraogo, M., Servat, E., Mahe, G., Dezetter, A., and Boyer, J. F.: The concept of rainfall and streamflow normals in West and Central Africa in a context of climatic variability, Hydrolog. Sci. J., 48, 125-138, 2003.

Paturel, J. E., Barrau, C., Mahé, G., Dezetter, A., and Servat, E.: Modelling the impact of climatic variability on water resources in West and Central Africa from a non-calibrated hydrological model, Hydrolog. Sci. J., 52, 38-48, doi:10.1623/hysj.52.1.38, 2007.

Roudier, P. and Mahé, G.: Calculation of design rainfall and runoff on the Bani basin (Mali): A study of the vulnerability of hydraulic structures and of the population since the drought, Hydrolog. Sci. J., 55, 351-363, 2010.

Roudier, P., Sultan, B., Quirion, P., and Berg, A.: The impact of future climate change on West African crop yields: what does the recent literature say?, Global Environ. Change, 21, 1073-1083, 2011.

Ruelland, D., Ardoin-Bardin, S., Collet, L., and Roucou, P.: Simulating future trends in hydrological regime of a large SudanoSahelian catchment under climate change, J. Hydrol., 424-425, 207-216, doi:10.1016/j.jhydrol.2012.01.002, 2012.

Shi, X., Mao, J., Thornton, P. E., Hoffman, F. M., and Post, W. M.: The impact of climate, $\mathrm{CO}_{2}$, nitrogen deposition and land use change on simulated contemporary global river flow, Geophys. Res. Lett., 38, L08704, doi:10.1029/2011g1046773, 2011.
Skinner, J., Niasse, M., and Haas, L.: Partage des bénéfices issus des grands barrages en Afrique de l'Ouest, IIED, London, UK, 2009.

Sterling, S. M., Ducharne, A., and Polcher, J.: The impact of global land-cover change on the terrestrial water cycle, Nat. Clim. Change, 3, 385-390, 2013.

Strzepek, K. and McCluskey, A.: District level hydroclimatic time series and scenario analyses to assess the impacts of climate change on regional water resources and agriculture in Africa, CEEPA Discussion Paper 13, University of Pretoria, Pretoria, South Africa, 2006.

Sultan, B.: Etude de la mise en place de la mousson en Afrique de l'Ouest et de la variabilité intra-saisonnière de la convection, Applications à la sensibilité des rendements agricoles, $\mathrm{PhD}$, University Paris VII - Denis Diderot, Paris, 283 pp., 2002.

Sultan, B., Roudier, P., Quirion, P., Alhassane, A., Muller, B., Dingkuhn, M., Ciais, P., Guimberteau, M., Traore, S., and Baron, C.: Assessing climate change impacts on sorghum and millet yields in the Sudanian and Sahelian savannas of West Africa, Environ. Res. Lett., 8, 014040, doi:10.1088/1748-9326/8/1/014040, 2013.

Tubiello, F. N., Amthor, J. S., Boote, K. J., Donatelli, M., Easterling, W., Fischer, G., Gifford, R. M., Howden, M., Reilly, J., and Rosenzweig, C.: Crop response to elevated $\mathrm{CO}_{2}$ and world food supply. A comment on "Food for Thought ..." by Long et al., Science, 312, 1918-1921, 2006, Eur. J. Agron., 26, 215-223, 2007.

UNECA and ACPC: Climate Change and Water in Africa: Analysis of Knowledge Gaps and Needs, Working Paper 4, 2011.

van Vliet, M. T. H., Franssen, W. H. P., Yearsley, J. R., Ludwig, F., Haddeland, I., Lettenmaier, D. P., and Kabat, P.: Global river discharge and water temperature under climate change, Global Environ. Change, 23, 450-464, doi:10.1016/j.gloenvcha.2012.11.002, 2013.

Vigaud, N., Roucou, P., Fontaine, B., Sijikumar, S., and Tyteca, S.: WRF/ARPEGE-CLIMAT simulated climate trends over West Africa, Clim. Dynam., 36, 925-944, doi:10.1007/s00382-0090707-4, 2011.

Wittig, R., König, K., Schmidt, M., and Szarzynski, J.: A Study of Climate Change and Anthropogenic Impacts in West Africa, Environ. Sci. Pollut. Res., 14, 182-189, 2007.

Wuebbles, D. and Ciuro, D.: Radiatively Important Atmospheric Constituents, in: Engineering Response to Climate Change, 2nd Edn., CRC Press, Boca Raton, USA, 45-48, 2013. 